\title{
Effects of Additional Glycine in Outpatients Being Treated for Urine Storage Disorders
}

\section{Kimio Sugaya ${ }^{1,2^{*}}$, Hitoshi Oh-0ka3, Tetsuo Yamada4, Masanobu Miyata ${ }^{5}$, Katsuhiro Ashitomi' ${ }^{2,6}$, Katsumi Kadekawa ${ }^{2,7}$, Saori Nishijima ${ }^{2}$}

\author{
${ }^{1}$ Department of Urology, Kitakami Central Hospital, Okinawa, Japan \\ ${ }^{2}$ Southern Knights' Laboratory, Okinawa, Japan \\ ${ }^{3}$ Kobe Medical Center, Kobe, Japan \\ ${ }^{4}$ Yamada Urological Clinic, Sagamihara, Japan \\ ${ }^{5}$ Kitanodai Clinic, Kitahiroshima, Japan \\ ${ }^{6}$ Department of Urology, Okinawa Hokubu Hospital, Okinawa, Japan \\ ${ }^{7}$ Department of Urology, Okinawa Kyodo Hospital, Okinawa, Japan \\ Email: *sugaya@sklabo.co.jp, katsuaki00311@yahoo.co.jp, kadekawa_k@yahoo.co.jp,nishijima@sklabo.co.jp, \\ bighill@zeus.eonet.ne.jp, kotsubanntei@yahoo.co.jp, miyajin_miya@yahoo.co.jp
}

How to cite this paper: Sugaya, K. Oh-Oka, H., Yamada, T., Miyata, M., Ashitomi, K., Kadekawa, K. and Nishijima, S. (2021) Effects of Additional Glycine in Outpatients Being Treated for Urine Storage Disorders. Open Journal of Urology, 11, 381-392.

https://doi.org/10.4236/oju.2021.1111037

Received: September 17, 2021

Accepted: November 1, 2021

Published: November 4, 2021

Copyright (c) 2021 by author(s) and Scientific Research Publishing Inc. This work is licensed under the Creative Commons Attribution International License (CC BY 4.0).

http://creativecommons.org/licenses/by/4.0/

\section{cc) (i) Open Access}

\begin{abstract}
Objectives: This study aimed to determine whether additional glycine can improve urine storage symptoms in outpatients. Methods: We recruited 50 outpatients (15 females, 35 males) with an Overactive Bladder Symptom Score (OABSS) of 3 or more. Participants being treated for urine storage disorders took additional glycine for 8 weeks at a dose of $3 \mathrm{~g}$ twice a day. Outcome measures included blood pressure, the International Prostate Symptom Score (IPSS), OABSS, Nocturia Quality of Life (N-QOL) score, urination frequency, sleep latency, time until the first void at night, bladder pain, improvement in urinary symptoms assessed with the Global Self-Assessment (GSA), and adverse events. Results: In the OABSS, the number of nighttime voids, urgency to urinate, urgent incontinence, and total score were improved. Improvements were also found in the IPSS total score for urine storage items, blood pressure, IPSS-QOL, time to first void, bladder pain, and GSA score, but no changes were seen in the frequency of urination at night, sleep latency or N-QOL score. No adverse events were recorded. Conclusion: Oral glycine improves objective and self-assessed urine storage symptoms, blood pressure, and bladder pain.
\end{abstract}

\section{Keywords}

Chronic Prostatitis, Glycine, Interstitial Cystitis, Overactive Bladder, Urine Storage Symptoms 


\section{Introduction}

The amino acid glycine is commonly used not only as a sweetener but also as an over-the-counter supplement for improving the quality of sleep, and it has not been found to have any adverse effects [1]. Endogenous glycine acts as the main inhibitor of neurotransmission in the spinal cord [2], and this inhibition plays an essential role in the micturition reflex [2] [3] and sensitivity to pain [4] [5]. Glycine levels decrease after spinal cord injury, and men with benign prostatic hyperplasia also have lower levels than healthy individuals [6]. Studies in rats showed that, as glycine levels decrease, bladder activity increases, bladder contractions are more frequent, and the maximum bladder contraction pressure is higher [3] [7]. Other studies in rats showed that oral glycine (administered as $1 \%$ to $3 \%$ of the diet) reduces both the frequency of bladder contractions and the maximum contraction pressure [8] [9] [10].

Previously, in a 4-week study, we compared oral glycine ( $3 \mathrm{~g}$ twice a day) with glucose in 20 patients receiving treatment for urine storage symptoms and found greater improvements by additional glycine in urine storage symptoms, cardiovascular function, bladder pain, and sleep quality [11]. Because this study had a small sample size, we subsequently performed an 8-week study of glycine versus glucose in a larger sample. Unfortunately, the drop-out rate was extremely high in the glucose group because of insufficient symptom improvement; however, an encouraging finding was that no patients in the glycine group discontinued the study at least for 4 weeks. Therefore, we aimed to conduct a single-blind, uncontrolled study to evaluate the effects of oral glycine in ameliorating symptoms of urine storage.

\section{Materials and Methods}

\subsection{Study Participants}

We recruited 50 males and females outpatients being treated at six urological clinics in Japan (Kitakami Central Hospital, Kobe Medical Center, Yamada Urological Clinic, Kitanodai Clinic, Okinawa Hokubu Hospital, and Okinawa Kyodo Hospital) from April 2013 to April 2016. Patients were eligible to participate if they were aged 20 years and older and had urine storage symptoms that showed no improvement after 8 weeks of standard treatment; a diagnosis of overactive bladder, chronic prostatitis, or bladder pain syndrome/interstitial cystitis; and an Overactive Bladder Symptom Score (OABSS) [12] of 3 or more. Exclusion criteria included urinary tract infection; relevant untreated organic diseases, such as benign prostatic hyperplasia with urine voiding symptoms, prostate cancer, bladder neck obstruction (sclerosis), stricture of the urethra, and bladder tumor or stones; $100 \mathrm{~mL}$ or more of residual urine after voiding; and a lack of urgency to urinate. Participants were permitted to continue taking all their regular medications.

The study protocol was approved by the Okinawa Kyodo Hospital Ethics Committee (approval no. 2012-005) for all participating institutions. All patients 
provided written informed consent to participate.

\subsection{Study Drug}

Although the study was uncontrolled, participants were informed that they would be assigned to receive small pouches containing either glucose or glycine. However, all participants actually received glycine (Nippon Garlic Corporation, Takasaki, Japan) at a dose of $3 \mathrm{~g}$ twice a day (morning and evening). The dose was chosen as being equivalent to about $1 \%$ of the dry weight of an adult man's daily food intake.

\subsection{Outcome Measures}

The following variables were assessed at baseline and after 4 and 8 weeks of treatment: overall clinical status; blood pressure and pulse rate; number of daytime voids; sleep latency; time until first nighttime void; and number of nighttime voids. At the same visits, patients also completed the following self-assessment tools: International Prostate Symptom Score (IPSS) (Appendix 1) [13]; IPSS quality of life (IPSS-QOL); OABSS (Appendix 2); nocturia quality of life (N-QOL) (Appendix 3) [14]; and visual analogue scale for bladder pain.

Transabdominal ultrasonography was performed at baseline to assess prostate volume and at baseline and the end of the study to assess the volume of residual urine after voiding. After 4 and 8 weeks, patients completed a global self-assessment (GSA) scale to assess changes in symptoms, as follows: 0 , excellent improvement; 1, good improvement; 2, fair improvement; 3, no change; 4, worse. Adverse events were recorded at weeks 4 and 8 .

\subsection{Statistical Analysis}

Results are reported as the mean \pm standard deviation. Higher scores corresponded to worse outcomes in all self-assessment tools except the N-QOL, in which a higher score corresponded to a better outcome. Changes over time were analyzed by Student's $t$-test for paired data, and significance was set as a $\mathrm{p}$ value of less than 0.05 .

\section{Results}

The 50 participants comprised 35 males and 15 females with a mean body mass index of $23.4 \pm 3.2$ and a mean age of $66 \pm 15$ years. Diagnoses were as follows: chronic prostatitis with overactive bladder (15 males); mild benign prostatic hyperplasia with overactive bladder (9 males); bladder pain syndrome/interstitial cystitis with overactive bladder ( 5 males and 12 females); and overactive bladder (6 males and 3 females) (Table 1). Concomitant diagnoses were hypertension in 12 patients and type 2 diabetes in 7 . The mean prostate size was $21.9 \pm 7.8 \mathrm{~mL}$ (range, 12.3 - $35.7 \mathrm{~mL}$ ). Concomitant medication included anti-muscarinic drugs for overactive bladder $(\mathrm{n}=39)$ and anti-muscarinic tricyclic antidepressants for bladder pain syndrome/interstitial cystitis $(n=11)$. Nine patients with benign 
Table 1. Characteristics of patients.

\begin{tabular}{clc}
\hline Sex & \multicolumn{1}{c}{ Diagnosis } & Number of cases \\
\hline Male & Chronic prostatitis with overactive bladder & 15 \\
& $\begin{array}{l}\text { Benign prostatic hyperplasia with overactive bladder } \\
\text { Bladder pain syndrome/interstitial cystitis with overactive } \\
\text { bladder }\end{array}$ & 5 \\
Overactive bladder & 6
\end{tabular}

total 35

$\begin{array}{ll}\text { Female } \begin{array}{l}\text { Bladder pain syndrome/interstitial cystitis with overactive } \\ \text { bladder }\end{array} & 12 \\ & \text { Overactive bladder }\end{array}$

total 15

prostatic hyperplasia were also receiving an alpha-1 blocker, and fifteen with chronic prostatitis, an anti-inflammatory botanical preparation.

At 4 weeks, we found a decrease in diastolic blood pressure compared with baseline (baseline: $67.2 \pm 10.5 \mathrm{mmHg}$ vs 4 week after: $65.1 \pm 10.5 \mathrm{mmHg}, \mathrm{p}<$ $0.05)$, but no change in systolic blood pressure $(124.7 \pm 17.3 \mathrm{mmHg}$ vs $123.3 \pm$ $17.3 \mathrm{mmHg}$, respectively) or pulse rate $(75.0 \pm 13.2 / \mathrm{min}$ vs $73.3 \pm 12.5 / \mathrm{min}$, respectively) (Table 2). The IPSS showed an improvement in total score, urgency to urinate, and total score of items related to urine storage. The OABSS showed improvements in total score, number of nighttime voids, urgency to urinate, and urge incontinence. Regarding quality of life, the IPSS-QOL score improved, as did the total score and total score of items about worries on the N-QOL. The number of day- and nighttime voids, bladder pain, and sleep latency showed no changes, but the time until the first void at night improved.

At 8 weeks, we found a decrease in systolic (baseline: $124.7 \pm 17.3 \mathrm{mmHg}$ vs 8 week after: $121.2 \pm 15.5 \mathrm{mmHg}, \mathrm{p}<0.05)$ and diastolic blood pressure compared with baseline $(67.2 \pm 10.5 \mathrm{mmHg}$ vs $65.1 \pm 10.5 \mathrm{mmHg}$, respectively, $\mathrm{p}<0.05)$ but no change in pulse rate $(75.0 \pm 13.2 / \mathrm{min}$ vs $73.4 \pm 14.2 / \mathrm{min}$, respectively). The IPSS showed an improvement in total score, frequency of urination, nocturia, and total score of items related to urine storage. In the OABSS, the same improvements from baseline were seen at 4 weeks. IPSS-QOL score was higher than at baseline, but neither the N-QOL total score nor any of the individual items showed an improvement from baseline. Neither the number of day- and nighttime voids nor sleep latency showed an improvement from baseline. The time until the first void at night was still higher than at baseline, and bladder pain improved slightly, but significantly. The volume of residual urine after voiding showed no change from baseline to 8 weeks $(27.8 \pm 26.6 \mathrm{~mL}$ vs $28.6 \pm$ $25.9 \mathrm{~mL}$, respectively).

Mean GSA scores showed a fair improvement at both $4(2.4 \pm 0.8)$ and 8 weeks $(2.2 \pm 1.1)$, and no adverse events were recorded at either visit. 
Table 2. Comparison of parameters and slf-assessed questionnaires between before and after glycine treatments.

\begin{tabular}{|c|c|c|c|c|c|c|c|c|c|}
\hline & \multicolumn{3}{|c|}{ Before } & \multicolumn{3}{|c|}{4 weeks after } & \multicolumn{3}{|c|}{8 weeks after } \\
\hline Number of cases & \multicolumn{3}{|c|}{50} & \multicolumn{3}{|c|}{50} & \multicolumn{3}{|c|}{40} \\
\hline \multicolumn{10}{|l|}{ Blood pressure (mmHg) } \\
\hline Systolic & 124.7 & \pm & 17.3 & 123.3 & \pm & 17.3 & 121.2 & \pm & $15.5^{\star}$ \\
\hline Diastolic & 67.2 & \pm & 10.5 & 65.1 & \pm & $10.5^{\star}$ & 65.1 & \pm & $10.5^{\star}$ \\
\hline Pulse rate $(/ \mathrm{min})$ & 75.0 & \pm & 13.2 & 73.3 & \pm & 12.5 & 73.4 & \pm & 14.2 \\
\hline \multicolumn{10}{|l|}{ IPSS } \\
\hline Incomplate emptying & 1.2 & \pm & 1.2 & 1.0 & \pm & 1.1 & 1.1 & \pm & 1.2 \\
\hline Frequency & 2.8 & \pm & 1.6 & 2.6 & \pm & 1.5 & 2.3 & \pm & $1.6^{*}$ \\
\hline Intermittency & 1.3 & \pm & 1.6 & 1.2 & \pm & 1.4 & 1.1 & \pm & 1.3 \\
\hline Urgency & 1.9 & \pm & 1.5 & 1.3 & \pm & $1.2^{\star *}$ & 1.6 & \pm & 1.4 \\
\hline Weak stream & 2.0 & \pm & 1.7 & 1.9 & \pm & 1.7 & 1.9 & \pm & 1.5 \\
\hline Straining & 1.0 & \pm & 1.4 & 0.8 & \pm & 1.2 & 0.8 & \pm & 1.3 \\
\hline Nocturia & 2.1 & \pm & 1.2 & 2.0 & \pm & 1.3 & 1.8 & \pm & $1.3^{*}$ \\
\hline Voiding Total & 4.3 & \pm & 3.9 & 3.9 & \pm & 3.5 & 3.7 & \pm & 3.2 \\
\hline Storage Total & 6.6 & \pm & 3.1 & 5.8 & \pm & $2.8^{\star \star}$ & 5.6 & \pm & $3.4^{\star *}$ \\
\hline Total score & 12.3 & \pm & 6.2 & 10.8 & \pm & $6.2^{\star \star}$ & 10.4 & \pm & $6.9^{*}$ \\
\hline IPSS-QOL & 4.7 & \pm & 1.2 & 4.1 & \pm & $1.5^{\star \star}$ & 3.6 & \pm & $1.6^{* *}$ \\
\hline \multicolumn{10}{|l|}{ Urinary frequency (times) } \\
\hline Diurnal & 10.5 & \pm & 3.4 & 10.8 & \pm & 6.7 & 10.6 & \pm & 7.3 \\
\hline Nocturnal & 2.1 & \pm & 1.3 & 1.9 & \pm & 1.6 & 1.7 & \pm & 1.7 \\
\hline \multicolumn{10}{|l|}{ OABSS } \\
\hline Diurnal urination & 1.2 & \pm & 0.9 & 1.1 & \pm & 0.5 & 1.0 & \pm & 0.6 \\
\hline Nocturnal urination & 2.0 & \pm & 0.8 & 1.8 & \pm & $0.9^{* *}$ & 1.5 & \pm & $0.9^{* *}$ \\
\hline Urgency & 2.5 & \pm & 1.6 & 2.0 & \pm & $1.5^{\star \star}$ & 1.8 & \pm & $1.4^{\star *}$ \\
\hline Incontinence & 1.3 & \pm & 1.6 & 1.1 & \pm & $1.5^{\star}$ & 0.9 & \pm & $1.3^{*}$ \\
\hline Total score & 7.0 & \pm & 3.6 & 6.0 & \pm & $3.4^{\star *}$ & 5.3 & \pm & $3.4^{\star *}$ \\
\hline \multicolumn{10}{|l|}{ N-QOL } \\
\hline Q1 & 2.9 & \pm & 0.9 & 3.1 & \pm & $0.9^{*}$ & 3.1 & \pm & 1.1 \\
\hline Q2 & 2.9 & \pm & 1.0 & 2.8 & \pm & 1.0 & 2.9 & \pm & 1.2 \\
\hline Q3 & 2.4 & \pm & 1.2 & 2.6 & \pm & 1.2 & 2.5 & \pm & 1.2 \\
\hline Q4 & 2.9 & \pm & 1.0 & 3.0 & \pm & 0.9 & 2.9 & \pm & 1.1 \\
\hline Q5 & 2.7 & \pm & 1.2 & 3.3 & \pm & 3.2 & 2.9 & \pm & 1.2 \\
\hline Q6 & 2.4 & \pm & 1.3 & 2.7 & \pm & 1.0 & 2.7 & \pm & 1.1 \\
\hline Q7 & 2.2 & \pm & 1.1 & 2.3 & \pm & 1.2 & 2.4 & \pm & 1.2 \\
\hline Q8 & 3.6 & \pm & 1.0 & 3.7 & \pm & 0.8 & 3.6 & \pm & 0.9 \\
\hline Q9 & 3.1 & \pm & 1.1 & 3.2 & \pm & 0.9 & 3.2 & \pm & 1.1 \\
\hline
\end{tabular}


Continued

\begin{tabular}{lccccccccc}
\hline Q10 & 2.4 & \pm & 1.3 & 2.6 & \pm & 1.2 & 2.7 & \pm & 1.0 \\
Q11 & 2.4 & \pm & 1.2 & 2.5 & \pm & 1.3 & 2.8 & \pm & 1.3 \\
Q12 & 2.3 & \pm & 1.2 & 2.6 & \pm & 1.1 & 2.6 & \pm & 1.3 \\
Q13 & 3.9 & \pm & 2.7 & 3.4 & \pm & 2.7 & 3.3 & \pm & 3.0 \\
Vitality Total & 16.0 & \pm & 5.2 & 17.2 & \pm & 6.1 & 16.8 & \pm & 5.9 \\
$\quad$ Worries Total & 16.1 & \pm & 5.5 & 17.3 & \pm & $4.9^{*}$ & 17.4 & \pm & 5.4 \\
$\quad$ Total score & 35.9 & \pm & 7.6 & 37.9 & \pm & $8.1^{*}$ & 37.5 & \pm & 8.3 \\
\hline Sleep latency (min) & 24.6 & \pm & 20.6 & 23.3 & \pm & 19.5 & 21.2 & \pm & 19.6 \\
First nocturia latency (min) & 181.5 & \pm & 93.9 & 203.9 & \pm & $93.2^{* *}$ & 206.5 & \pm & $94.8^{*}$ \\
Bladder pain (VAS) & 2.3 & \pm & 2.9 & 1.8 & \pm & 2.5 & 1.8 & \pm & $2.8^{*}$ \\
Global self-assessment & & & & 2.4 & \pm & 0.8 & 2.2 & \pm & 1.1 \\
\hline
\end{tabular}

The larger is the number, the better is the N-QOL, but the worse is the other questionnaires. Mean \pm standard deviation. ${ }^{*}: \mathrm{p}<0.05,{ }^{* *}$ : $\mathrm{p}<0.01$ vs before.

\section{Discussion}

The current study found that 8 weeks' administration of oral glycine improved urine storage symptoms such as nocturia, urgency to urinate, and urge incontinence; patient quality of life; and bladder pain. These findings are in line with our earlier 4-week study that compared glycine with glucose, although that study also found improvements in sleep [11]. Both studies also found a decrease in blood pressure but no change in pulse rate. Taken together, these findings indicate that oral glycine has positive effects on urine storage symptoms, blood pressure, and bladder pain.

Oral glycine given at a dose of $1 \%$ to $3 \%$ of food weight was found to increase the time between bladder contractions in healthy rats [8] and in those with pelvic vein congestion [10] and to reduce the strength of bladder contractions in rats with spinal cord injury [8]. Another study in rats found that orally administered glycine increased glycine levels in brain tissue, indicating that glycine can cross the blood-brain barrier [15]. Both our earlier [11] and the present study found that symptoms improved in patients receiving anti-muscarinic drugs for urine storage symptoms. These drugs usually have a peripheral action [16], and our findings indicate that concomitant treatment with centrally acting glycine may result in further improvement of symptoms.

Although both the IPSS and OABSS showed improvements in nighttime urinary parameters in the current study, the number of nighttime voids did not improve significantly. This result is in contrast to our previous study, where the number of nighttime voids decreased significantly after 4 weeks' administration of glycine [11]. The maximum possible score for nighttime voids is 5 on the IPSS and 3 on the OABSS, even if the actual number of voids is higher. Therefore, any reduction in the number of nighttime voids to a number that is still above 5 (IPSS) or 3 (OABSS) will not be recorded, even though the change may be sig- 
nificant. The large standard deviation in our data may also explain why our current study found no significant improvement in the number of nighttime voids.

Glycinergic interneurons in the spine may help regulate neurotransmission of pain and reduce neuropathic pain [5] and may also decrease sensitivity to pain [4]. Consequently, glycine probably can also reduce bladder pain, which may explain our respective findings.

Glycine is widely used at a dose of $3 \mathrm{~g}$ as an over-the-counter supplement for sleep and has no known side effects [1]. It inhibits orexin neurons, which stimulate active wakefulness, and increases the duration of non-rapid eye movement sleep [17]. In addition, it binds to $\mathrm{N}$-methyl-D-aspartate receptors in the suprachiasmatic nucleus shell, leading to dilation of peripheral blood vessels, which promotes sleep [18]. Our earlier study confirmed the sleep-promoting effects of glycine [11]; however, the current study did not, which may be a chance finding related to the time of glycine administration: Participants were instructed to take the two doses of glycine at different times (morning and evening) each day, but the exact times were not specified. Future studies need to evaluate whether administering glycine at bedtime has positive effects on sleep.

The finding in the present study that systolic and diastolic blood pressure decreased after 4 to 8 weeks' administration of glycine may be related to the peripheral vasodilation caused by binding of glycine to N-methyl-D-aspartate receptors in the suprachiasmatic nucleus shell [18]. Glycine also binds to these receptors in the rostral ventral medulla, an area involved in the maintenance of arterial baroreceptor reflex [19]. Furthermore, a study in rats with diabetes showed that oral glycine leads to an increase in blood nitric oxide levels, resulting in vasodilation [20]. These central and peripheral effects of glycine may act together to reduce blood pressure.

There are limitations of the current study. Although our previous 4-week study comparing oral glycine with glucose as a placebo found greater improvements by additional glycine in urine storage symptoms, cardiovascular function, bladder pain, and sleep quality [11], this study had a small sample size. In the current study, we started an 8-week study of glycine versus glucose in a larger sample. However, the drop-out rate was extremely high in the glucose group. Therefore, it was not possible to compare the effects of glycine and placebo, and we conducted a single-blind, uncontrolled study but not double-blind, controlled study to evaluate the effects of oral glycine.

Nighttime urination has a negative effect on the quality of life, but the frequency of voiding is not the only related issue reported by patients [21] [22]. Other problems include time to first nighttime voiding and bladder pain, both of which improved in the present study, as did the OABSS, which reflects many related symptoms. These positive changes may explain the increase in IPSS-QOL and GSA scores.

\section{Conclusion}

Glycine appears to improve symptoms of urine storage, blood pressure, and 
bladder pain. It does not cause any adverse events or increase the volume of residual urine after voiding. Furthermore, it is inexpensive. Therefore, we suggest that glycine is a safe concomitant treatment for urine storage symptoms and bladder pain and may be particularly useful in patients with hypertension.

\section{Conflicts of Interest}

The authors declare no conflicts of interest regarding the publication of this paper.

\section{References}

[1] Yamadera, W., Inagawa, K., Chiba, S., Bannai, M., Takahashi, M. and Nakayama, K. (2007) Glycine Ingestion Improves Subjective Sleep Quality in Human Volunteers, Correlating with Polysomnographic Changes. Sleep and Biological Rhythms, 5, 126-131. https://doi.org/10.1111/j.1479-8425.2007.00262.x

[2] Sugaya, K., Nishijima, S., Miyazato, M. and Ogawa, Y. (2005) Central Nervous Control of Micturition and Urine Storage. Journal of Smooth Muscle Research, 41, 117-132. https://doi.org/10.1540/jsmr.41.117

[3] Nishijima, S., Sugaya, K., Miyazato, M., Ashitomi, K., Morozumi, M. and Ogawa, Y. (2003) Changes of Bladder Activity and Glycine Levels in the Spinal Cord and Serum after Spinal Cord Injury in Rats. Biomedical Research (Tokyo), 24, 165-171. https://doi.org/10.2220/biomedres.24.165

[4] Al-Khrasani, M., Mohammadzadeh, A., Balogh, M., Király, K., Barsi, S., Hajnal, B., Köles, L., Zádori, Z.S. and Harsing, L.G.Jr. (2019) Glycine Transporter Inhibitors: A New Avenue for Managing Neuropathic Pain. Brain Research Bulletin, 152, 143-158. https://doi.org/10.1016/j.brainresbull.2019.07.008

[5] Cioffi, C.L. (2018) Modulation of Glycine-Mediated Spinal Neurotransmission for the Treatment of Chronic Pain. Journal of Medical Chemistry, 61, 2652-2679. https://doi.org/10.1021/acs.jmedchem.7b00956

[6] Nishijima, S., Sugaya, K., Fukuda, T., Miyazato, M., Ashimine, S. and Ogawa, Y. (2006) Serum Amino Acids as Indicators of Cerebrospinal Neuronal Activity in Patients with Micturition Disorders. International Journal of Urology, 13, 1479-1483. https://doi.org/10.1111/j.1442-2042.2006.01653.x

[7] Nishijima, S., Sugaya, K., Miyazato, M., Ashitomi, K., Morozumi, M. and Ogawa, Y. (2003) Relationship between Bladder Activity and Amino Acid Levels in the Central Nervous System in Rats with Cerebral Infarction. Biomedical Research (Tokyo), 24, 173-180. https://doi.org/10.2220/biomedres.24.173

[8] Miyazato, M., Sugaya, K., Nishijima, S., Ashitomi, K., Morozumi, M. and Ogawa, Y. (2005) Dietary Glycine Inhibits Bladder Activity in Normal Rats and Rats with Spinal Cord Injury. Journal of Urology, 173, 314-317. https://doi.org/10.1097/01.ju.0000141579.91638.a3

[9] Miyazato, M., Sugaya, K., Nishijima, S., Kadekawa, K., Ashimine, S. and Ogawa, Y. (2005) Intrathecal or Dietary Glycine Inhibits Bladder and Urethral Activity in Rats with Spinal Cord Injury. Journal of Urology, 174, 2397-2400. https://doi.org/10.1097/01.ju.0000180415.69705.7a

[10] Sugaya, K., Nishijima, S., Kadekawa, K., Noguchi, K., Ueda, T. and Yamamoto, H. (2019) Spinal Glycinergic and GABAergic Neurons Inhibit the Micturition Reflex after Electrical Stimulation of the Perineum in Rats with Pelvic Venous Congestion. International Journal of Urology, 26, 1149-1155. https://doi.org/10.1111/iju.14116 
[11] Sugaya, K., Oh-oka, H., Yamada, T., Miyata, M., Ashitomi, K., Kadekawa, K. and Nishijima, S. (2021) Dietary Glycine Improves Urine Storage Symptoms in Urology Outpatients. Journal of Complementary \& Integrative Medicine, 18, 617-620. https://doi.org/10.1515/jcim-2020-0282

[12] Homma, Y., Yoshida, M., Seki, N., Yokoyama, O., Kakizaki, H., Gotoh, M., Yamanishi, T., Yamaguchi, O., Takeda, M. and Nishizawa, O. (2006) Symptom Assessment Tool for Overactive Bladder Syndrome-Overactive Bladder Symptom Score. Urology, 68, 318-323. https://doi.org/10.1016/j.urology.2006.02.042

[13] Barry, M.J., Fowler, F.J.Jr., O’Leary, M.P., Bruskewitz, R.C., Holtgrewe. H.L., Mebust, W.K. and Cockett, A.T. (1992) The American Urological Association Symptom Index for Benign Prostatic Hyperplasia. The Measurement Committee of the American Urological Association. Journal of Urology, 148, 1549-1557. https://doi.org/10.1016/S0022-5347(17)36966-5

[14] Abraham, L., Hareendran, A., Mills, I.W., Martin, M.L., Abrams, P., Drake, M.J., MacDonagh, R.P. and Noble, J.G. (2004) Development and Validation of a Quality-of-Life Measure for Men with Nocturia. Urology, 63, 481-486. https://doi.org/10.1016/j.urology.2003.10.019

[15] Kawai, N., Bannai, M., Seki, S., Koizumi, T., Shinkai, K., Nagao, K., Matsuzawa, D., Takahashi, M. and Shimizu, E. (2012) Pharmacokinetics and Cerebral Distribution of Glycine Administered to Rats. Amino Acids, 42, 2129-2137. https://doi.org/10.1007/s00726-011-0950-y

[16] Yamada, S., Ito, Y., Nishijima, S., Kadekawa, K. and Sugaya, K. (2018) Basic and Clinical Aspects of Antimuscarinic Agents Used to Treat Overactive Bladder. Pharmacology \& Therapeutics, 189, 130-148. https://doi.org/10.1016/j.pharmthera.2018.04.010

[17] Hondo, M., Furutani, N., Yamasaki, M., Watanabe, M. and Sakurai, T. (2011) Orexin Neurons Receive Glycinergic Innervations. PLoS ONE, 6, e25076. https://doi.org/10.1371/journal.pone.0025076

[18] Kawai, N., Sakai, N., Okuro, M., Karakawa, S., Tsuneyoshi, Y., Kawasaki, N., Takeda, T., Bannai, M. and Nishino, S. (2015) The Sleep-Promoting and Hypothermic Effects of Glycine Are Mediated by NMDA Receptors in the Suprachiasmatic Nucleus. Neuropsychopharmacology, 40, 1405-1416. https://doi.org/10.1038/npp.2014.326

[19] Gao, H., Korim, W.S., Yao, S.T., Heesch, C.M. and Derbenev, A.V. (2019) Glycinergic Neurotransmission in the Rostral Ventrolateral Medulla Controls the Time Course of Baroreflex-Mediated Sympathoinhibition. Journal of Physiology, 597, 283-301. https://doi.org/10.1113/JP276467

[20] Wang, Z., Zhang, J., Chen, L., Li, J., Zhang, H. and Guo, X. (2019) Glycine Suppresses AGE/RAGE Signaling Pathway and Subsequent Oxidative Stress by Restoring Glo1 Function in the Aorta of Diabetic Rats and in HUVECs. Oxidative Medicine and Cellular Longevity, 2019, Article ID: 4628962. https://doi.org/10.1155/2019/4628962

[21] Rose, G.E., Denys, M.A., Kumps, C., Whishaw, D.M., Khan, F., Everaert, K.C. and Bower, W.F. (2019) Nocturnal Voiding Frequency Does Not Describe Nocturia-Related Bother. Neurourology and Urodynamics, 38, 1648-1656. https://doi.org/10.1002/nau.24029

[22] Sugaya, K., Nishijima, S., Miyazato, M., Owan, T., Oshiro, Y., Uchida, A., Hokama, S. and Ogawa, Y. (2007) Investigation of Biochemical Factors Related to Non-Bothersome Nocturnal Urination. Biomedical Research (Tokyo), 28, 213-217. https://doi.org/10.2220/biomedres.28.213 


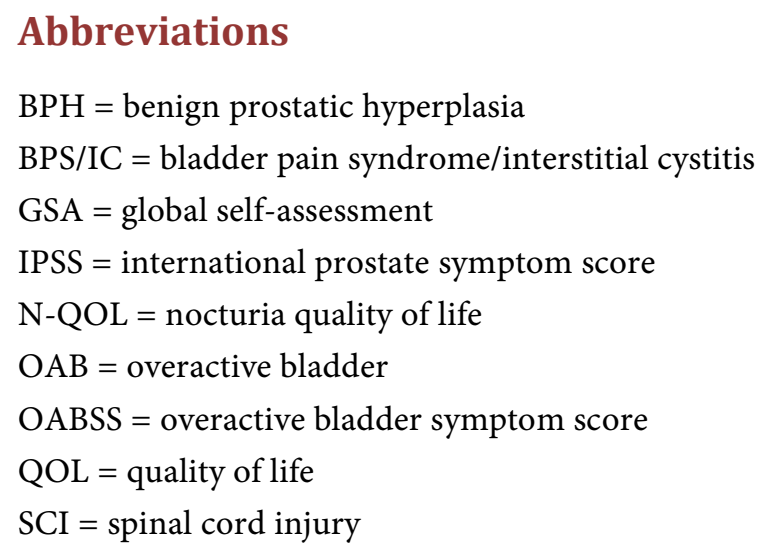

Appendix 1. International Prostate Symptom Score (IPSS)

\begin{tabular}{|c|c|c|c|c|c|c|}
\hline In the past month: & Not at All & $\begin{array}{l}\text { Less than } 1 \\
\text { in } 5 \text { Times }\end{array}$ & $\begin{array}{c}\text { Less than Half } \\
\text { the Time }\end{array}$ & $\begin{array}{c}\text { About Half } \\
\text { the Time }\end{array}$ & $\begin{array}{l}\text { More than } \\
\text { Half the Time }\end{array}$ & $\begin{array}{l}\text { Almost } \\
\text { Always }\end{array}$ \\
\hline
\end{tabular}

\section{Incomplete Emptying}

How often have you had the sensation of not emptying your 0 1 2 3 4 5 bladder?

\section{Frequency}

How often have you had to 0

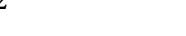

4

urinate less than every 2 hours?

\section{Intermittency}

How often have you found you stopped and started again several

1

12

3

3

4

5

times when you urinated?

\section{Urgency}

How often have you found it

0

1

2

3

4

5

difficult to postpone urination?

\section{Weak Stream}

How often have you had a weak

$0 \quad 1$

12

3

4

5

urinary stream?

\section{Straining}

How often have you had to strain

$0 \quad 1$

2

3

4

5

to start urination?

\begin{tabular}{lllllll}
\hline None & 1 Time & 2 Times & 3 Times & 4 Times & 5 Times \\
\hline
\end{tabular}

\section{Nocturia}

How many times did you typically 0

1

2

3

4

5 get up at night to urinate?

\section{Total IPSS Score}

Score:

1 - 7: Mild

8 - 19: Moderate

20 - 35: Severe 


\section{Continued}

Quality of Life Due to Urinary

Symptoms

If you were to spend the rest of your life with your urinary condition just the way it is now,

Appendix 2. Overactive Bladder Symptom Score (OABSS)

\begin{tabular}{|c|c|c|}
\hline & Score & Frequency \\
\hline \multirow{3}{*}{$\begin{array}{l}\text { How many times do you typically urinate } \\
\text { from waking in the morning until sleeping } \\
\text { at night? }\end{array}$} & 0 & 7 or less \\
\hline & 1 & $8-14$ \\
\hline & 2 & 15 or more \\
\hline \multirow{4}{*}{$\begin{array}{l}\text { How many times do you typically wake up } \\
\text { to urinate from sleeping at night until } \\
\text { waking in the morning? }\end{array}$} & 0 & 0 \\
\hline & 1 & 1 \\
\hline & 2 & 2 \\
\hline & 3 & 3 or more \\
\hline \multirow{6}{*}{$\begin{array}{l}\text { How often do you have a sudden desire to } \\
\text { urinate, which is difficult to defer? }\end{array}$} & 0 & not at all \\
\hline & 1 & less than once a week \\
\hline & 2 & once a week or more \\
\hline & 3 & about once a day \\
\hline & 4 & $2-4$ times a day \\
\hline & 5 & 5 times a day or more \\
\hline \multirow{6}{*}{$\begin{array}{l}\text { How often do you leak urine, because you } \\
\text { cannot defer the sudden desire to urinate? }\end{array}$} & 0 & not at all \\
\hline & 1 & less than once a week \\
\hline & 2 & once a week or more \\
\hline & 3 & about once a day \\
\hline & 4 & $2-4$ times a day \\
\hline & 5 & 5 times a day or more \\
\hline
\end{tabular}

OABSS (sum of scores) $=$ 


\section{Appendix 3. Nocturia Quality of Life Questionaire (N-QOL)}

The following statements are about the impact of "having to get up at night to urinate". For each item, please mark an (X) in the box next to the response that best describes how you have felt. Please mark only one box for each statement.

\section{OVER THE PAST 2 WEEKS, HAVING TO GET UP AT NIGHT TO URINATE ..........}

\begin{tabular}{|c|c|c|c|c|c|c|}
\hline & score & 4 & 3 & 2 & 1 & 0 \\
\hline 1 & $\begin{array}{l}\text { Has made it difficult for me to } \\
\text { concentrate the next day }\end{array}$ & $\square$ Every day & $\square$ Most days & $\square$ Some days & $\square$ Rarely & $\square$ Never \\
\hline 2 & $\begin{array}{l}\text { Has made me feel generally low in } \\
\text { energy the next day }\end{array}$ & $\square$ Every day & $\square$ Most days & $\square$ Some days & $\square$ Rarely & $\square$ Never \\
\hline 3 & $\begin{array}{l}\text { Has required me to nap during the } \\
\text { day }\end{array}$ & $\square$ Every day & $\square$ Most days & $\square$ Some days & $\square$ Rarely & $\square$ Never \\
\hline 4 & $\begin{array}{l}\text { Has made me less productive the } \\
\text { next day }\end{array}$ & $\square$ Every day & $\square$ Most days & $\square$ Some days & $\square$ Rarely & $\square$ Never \\
\hline 5 & $\begin{array}{l}\text { Has caused me to participate less } \\
\text { in activities I enjoy }\end{array}$ & $\square$ Extremely & $\square$ Quite a bit & $\square$ Moderately & $\square$ A little bit & $\square$ Not at all \\
\hline 6 & $\begin{array}{l}\text { Has caused me to be careful about } \\
\text { when or how much I drink }\end{array}$ & $\square$ All the time & $\square$ Most of the time & $\square$ Some of the time & $\square$ Rarely & $\square$ Never \\
\hline 7 & $\begin{array}{l}\text { Has made it difficult for me to get } \\
\text { enough sleep at night }\end{array}$ & $\square$ Every night & $\square$ Most nights & $\square$ Some nights & $\square$ Rarely & $\square$ Never \\
\hline \multicolumn{7}{|c|}{ OVER THE PAST 2 WEEKS, I HAVE BEEN ........... } \\
\hline 8 & $\begin{array}{l}\text { Concerned that I am disturbing } \\
\text { others in the house because of } \\
\text { having to get up at night to urinate }\end{array}$ & $\square$ Extremely & $\square$ Quite a bit & $\square$ Moderately & $\square$ A little bit & $\square$ Not at all \\
\hline 9 & $\begin{array}{l}\text { Preoccupied about having to get } \\
\text { up at night to urinate }\end{array}$ & $\square$ All the time & $\square$ Most of the time & $\square$ Some of the time & $\square$ Rarely & $\square$ Never \\
\hline 10 & $\begin{array}{l}\text { Worried that this condition will } \\
\text { get worse in the future }\end{array}$ & $\square$ Extremely & $\square$ Quite a bit & $\square$ Moderately & $\square$ A little bit & $\square$ Not at all \\
\hline & $\begin{array}{l}\text { Worried that there is no effective } \\
\text { treatment for this condition (having } \\
\text { to get up at night to urinate) }\end{array}$ & $\square$ Extremely & $\square$ Quite a bit & $\square$ Moderately & $\square$ A little bit & $\square$ Not at all \\
\hline 12 & \multicolumn{5}{|c|}{ Overall, how bothersome has having to get up at night to urinate been during the past 2 weeks? } & $\square$ Not at all \\
\hline 13 & 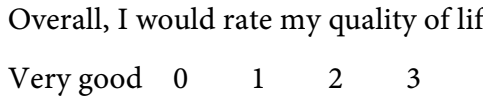 & to be ...... & 10 & Very poor & & \\
\hline
\end{tabular}

